\title{
Outsourcing with debt financing
}

\author{
João C. A. Teixeira
}

Received: 6 July 2012 / Accepted: 13 January 2014 / Published online: 8 February 2014

(C) ISEG 2014

\begin{abstract}
This paper investigates the effect of capital structure on a firm's choice between vertical integration and outsourcing. We model the production decision in a Principal-Agent framework and show that suppliers use debt as a strategic instrument to collect the surplus from outsourcing as their wealth constraint or limited liability ensures them more attractive compensation schemes. Investigating the buyer's capital structure, we find that outsourcing with risky debt is more likely to occur for high values of the outsourcing surplus.
\end{abstract}

Keywords Outsourcing · Capital structure · Incentives · Uncertainty

JEL Classifications D $81 \cdot \mathrm{G} 32 \cdot \mathrm{G} 33 \cdot \mathrm{L} 23 \cdot \mathrm{L} 24$

J. C. A. Teixeira

Department of Economics and Business and Centre of Applied Economic

Studies of the Atlantic, University of the Azores,

Rua Mãe de Deus, s/n, 9501-855 Ponta Delgada, Portugal

e-mail: jteixeira@uac.pt 